\title{
Photochemoprotective Effects of Ethyl Acetate Fraction from Senegalia polyphylla Leaves in Ultraviolet-Irradiated L929 Fibroblasts
}

\author{
Regina Gomes Daré1, Lilian dos Anjos Oliveira Ferreira', Fabianne Martins Ribeiro', Jesuí Vergilio Visentainer², \\ Celso Vataru Nakamura ${ }^{3}$, Maria da Conceição Torrado Truiti ${ }^{1, *}$
}

\section{Regina Gomes Daré1, Lilian dos Anjos Oliveira Ferreira', Fabianne Martins Ribeiro', Jesuí Vergilio Visentainer ${ }^{2}$, Celso Vataru Nakamura ${ }^{3}$, Maria da Conceição Torrado Truiti ${ }^{1, *}$}

'Departamento de Farmácia, Universidade Estadual de Maringá, Maringá, Paraná, BRAZIL.

${ }^{2}$ Departamento de Química, Universidade

Estadual de Maringá, Maringá, Paraná, BRAZIL.

${ }^{3}$ Departamento de Ciências Básicas da Saúde, Universidade Estadual de Maringá, Paraná, BRAZIL.

\section{Correspondence}

Dr. Maria C. T. Truiti

Departamento de Farmácia, Universidade Estadual de Maringá, Maringá-87020-900, Paraná, BRAZIL.

Phone no: + 554430113869

E-mail: mcttruiti@uem.br

\section{History}

- Submission Date: 03-05-2021;

- Review completed: 21-06-2021;

- Accepted Date: 05-07-2021.

DOI : 10.5530/fra.2021.1.2

Article Available online

http://www.antiox.org

\section{Copyright}

(C) 2021 Phcog.Net. This is an openaccess article distributed under the terms of the Creative Commons Attribution 4.0 International license.

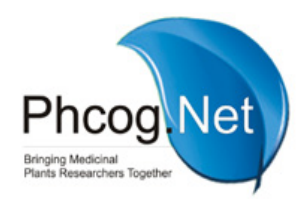

\section{ABSTRACT}

Objectives: Unprotected exposure to ultraviolet radiation causes oxidative damages to skin cells. Topical administration of antioxidants is a feasible strategy to prevent oxidative alterations. Therefore, the present study evaluated the photodamage attenuating potential of plant materials from Senegalia polyphylla leaves, due to previous studies relating Senegalia species as a source of antioxidant phenolic compounds. Materials and Methods: The ethanolic extract (EE) and its ethyl acetate (EAF), hydromethanolic and hexane fractions were evaluated for their total phenolic content and antioxidant capacity. The photochemoprotective effects of plant materials with higher antioxidant potential were assessed in L929 fibroblasts against ultraviolet-B (UVB) and Ultraviolet-A (UVA) radiations. Phytochemical investigation of bioactive plant material was performed and compounds identified by nuclear magnetic resonance analysis. Results: The $\mathrm{EE}$ and EAF presented the highest total phenolic content and antioxidant capacity, showing ferric reducing power and ability to scavenge free radicals DPPH $\bullet, A B T S \bullet, \mathrm{O}_{2} \bullet$ and $\mathrm{ROO} \bullet$. The EE and EAF treatments prior to UVB and UVA irradiation prevented the decrease in cell viability, and attenuated reactive oxygen species generation, reduced glutathione depletion, lipid peroxidation and plasma membrane disruption, especially with EAF treatment. Vitexin and isoquercetin, known antioxidant compounds, were isolated from EAF, which may be correlated with its photochemoprotective ability. Conclusion: Findings indicate the potential of polyphenol-enriched botanical materials, such as EAF from S. polyphylla, in preventing UVB and UVA-induced oxidative damages, due to its effective antioxidant activity and ability to attenuate redox imbalance and reduce cell damages.

Key words: Antioxidant activity, Free radicals, Oxidative stress, Phytochemicals, UVB.

\section{INTRODUCTION}

Ultraviolet (UV) radiation is a well-known environmental risk factor for initiation and development of different skin disorders. This radiation can be divided into three sections: ultraviolet C (UVC) (100-280 nm), ultraviolet B (UVB) (280-315 nm) and ultraviolet A (UVA) (315$400 \mathrm{~nm}$ ). Although UVC is screened out in the ozone layer, UVB and UVA reach Earth's surface in sufficient amount to inflict undesirable alterations on epidermal and dermal layers of the skin. ${ }^{1}$ Consequently, both radiations are able to affect keratinocytes, main cells of epidermis, and fibroblasts, main cells of dermis, ${ }^{2}$ mostly because they promote overproduction of reactive oxygen species (ROS), inducing a redox imbalance and oxidative damages in skin cells. ${ }^{3}$

Cumulative oxidative injuries due to long-term and recurrent UV exposure causes gradual deterioration of skin structure, leading to inflammation, photoaging, immunosuppression and increased risk of skin cancer. ${ }^{1}$ The use of sunscreen is the primary preventive measure for combating the deleterious effects of sunlight exposure. However, it is not sufficiently effective, and novel strategies for photoprotection are currently being explored. Considering that cell damage induced by UV is linked to ROS generation, one of these strategies is the topical administration of antioxidant agents, in order to prevent or attenuate oxidative stress. ${ }^{4}$

The genus Senegalia (Fabaceae) includes approximately 210 species. ${ }^{5}$ A number of these species have been shown to be a source of phenolic compounds, especially flavonoids, ${ }^{6-8}$ demonstrating antioxidant potential of their plant materials, such as extracts or purified fractions, due to their abilities to directly scavenge ROS and inhibit free radical generation. ${ }^{8,9}$ Senegalia polyphylla (DC.) Britton and Rose [synonyms: Acacia glomerosa Benth. and Senegalia glomerosa (Benth.) Britton and Rose] is a Brazilian plant popularly known as 'monjoleiro', 'guarucáia' and 'paricá-rana'. Phytochemical studies of this species have been restricted to the polysaccharide analysis of its gum. ${ }^{10}$ In this context, the objective of the present study was to investigate the antioxidant capacity and photochemoprotective potential of plant 
materials from S. polyphylla leaves. In addition, perform a phytochemical study of its bioactive botanical material.

\section{MATERIALS AND METHODS}

\section{Chemicals and Reagents}

All chemicals and solvents used were of analytical grade. DMEM (Dulbecco's modified Eagle's medium), fetal bovine serum (both from Gibco, Carlsbad, USA), neutral red (Interlab, São Paulo, Brazil), FolinCiocalteu (Dinâmica, São Paulo, Brazil), DPPP, $\mathrm{H}_{2}$ DCF-DA (both from Invitrogen, Carlsbad, USA), ABTS, BHT, DPPH, gallic acid, GSH, Hank's balanced salt solution, luminol, propidium iodide, quercetin, Trolox, xanthine and xanthine oxidase (Sigma-Aldrich, St Louis, USA).

\section{Plant Materials}

S. polyphylla leaves were collected in Estação Ecológica do Caiuá (Diamante do Norte, Paraná, Brazil). The identification was carried out by Dr. Mariza B. Romagnolo (voucher specimen, HUEM $n^{0}$ 26211). The leaves were dried at $40^{\circ} \mathrm{C}$ and ground using a knife mill. The ground leaves $(600.2 \mathrm{~g})$ were submitted to percolation with absolute ethanol at room temperature. The extract was concentrated under reduced pressure and lyophilized to obtain the ethanolic extract (EE; $101.4 \mathrm{~g}-16.9 \%$ yield). The EE (50.7 g) was dissolved in methanol:water 1:1 (v/v) and partitioned with $n$-hexane and ethyl acetate to obtain the hexane (HF; $15.4 \mathrm{~g}$ ), ethyl acetate (EAF; $15.9 \mathrm{~g}$ ) and hydromethanolic (MF; $15.7 \mathrm{~g}$ ) fractions.

\section{Total Phenolic Content}

The total phenolic (TP) content was measured using Folin-Ciocalteu reagent. In brief, $100 \mu \mathrm{L}$ of sample was mixed with $250 \mu \mathrm{L}$ of FolinCiocalteu reagent and $1 \mathrm{~mL}$ of sodium carbonate saturated solution. Then, the final volume was adjusted to $5 \mathrm{~mL}$ of distilled water. After $2 \mathrm{~h}$ of incubation in the dark at room temperature, the absorbance was measured at $760 \mathrm{~nm}$. A calibration curve was produced $(\mathrm{y}=3.248 \mathrm{x}+$ $\left.0.5737, \mathrm{r}^{2}=0.992\right)$ using standard gallic acid.

\section{Antioxidant Potential}

The ferric reducing antioxidant power (FRAP) assay was performed as described by Benzie and Strain, ${ }^{11}$ with standard Trolox used for the calibration curve. The scavenging activity of $\mathrm{ABTS}^{\cdot+}$ was performed as described by Re et al. ${ }^{12}$ with Trolox used for the calibration curve. The scavenging activity of $\mathrm{DPPH} \cdot$ was performed as Brand-Williams et al. ${ }^{13}$ the inhibition values were calculated as follows: $\left[\left(\mathrm{Abs}_{0}-\mathrm{Abs}_{1} / \mathrm{Abs}_{0}\right)\right.$ $\mathrm{x} 100]$, where $\mathrm{Abs}_{0}$ and $\mathrm{Abs}_{1}$ were the absorbance values without and with the addition of samples, respectively. The scavenging activity of ROO' was evaluated using the oxygen radical absorbance capacity (ORAC) assay, ${ }^{14}$ and Trolox used for the calibration curve. The scavenging activity of $\mathrm{O}_{2}{ }^{--}$was performed according to the xanthine/luminol/xanthine oxidase (XO) system, ${ }^{15}$ the inhibition values were calculated as follows: $\left[\left(\mathrm{L}_{0}-\mathrm{L}_{1} /\right.\right.$ $\mathrm{L}_{0}$ ) x100], where $\mathrm{L}_{0}$ and $\mathrm{L}_{1}$ were the luminescence values without and with the addition of samples, respectively.

\section{Photochemoprotective Activity}

\section{Cell Culture and Ultraviolet Irradiation}

L929 fibroblast (ATCC ${ }^{\circ}$ CCL-1 ${ }^{\mathrm{Tx}}$, Manassas, USA) were cultured in DMEM supplemented with $10 \%$ fetal bovine serum, penicillin (100 U/ $\mathrm{mL})$ and streptomycin $(100 \mu \mathrm{g} / \mathrm{mL})$ at $37^{\circ} \mathrm{C}$ in a $5 \% \mathrm{CO}_{2}$ atmosphere. Cells were exposed to UVB or UVA radiations using a chamber fitted with UVB lamp (TL40W/12RS; Philips; peak intensity of $312 \mathrm{~nm}$ ) at 400 $\mathrm{mJ} / \mathrm{cm}^{2}$ or with UVA lamps (TLK40W/10R; Philips; peak intensity of 365 $\mathrm{nm})$ at $12 \mathrm{~J} / \mathrm{cm}^{2}$. The radiation levels were monitored using a UV spectra radiometer (VLX-3W, Vilber Lourmat'). Prior to exposure, the culture medium was replaced with a thin layer of fresh HBSS to prevent UV absorption by proteins, and DMEM was replaced following irradiation.

\section{Cell Viability}

Fibroblasts cultured in 96-well plates $\left(2.5 \times 10^{5}\right.$ cells $\left./ \mathrm{mL}\right)$ were treated with EE or EAF $(2.5-200 \mu \mathrm{g} / \mathrm{mL})$ and incubated for $24 \mathrm{~h}$ at $37^{\circ} \mathrm{C}$ to assess plant materials effect on cell viability. For the evaluation of fibroblasts viability treated and irradiated, cells cultured in 24 -well plates $\left(2.5 \times 10^{5}\right.$ cells $/ \mathrm{mL})$ were treated for $1 \mathrm{~h}$ with EE or EAF $(2.5-20 \mu \mathrm{g} / \mathrm{mL})$, exposed to UVB or UVA, and incubated for $24 \mathrm{~h}$ at $37^{\circ} \mathrm{C}$. After the incubation periods, the neutral red assay was performed to evaluate cell viability. ${ }^{16}$ The absorbance was measured at $540 \mathrm{~nm}$ (Biochrom Asys' UVM 340), and cell viability was calculated in comparison to the control (nonirradiated and untreated cells).

\section{Intracellular Reactive Oxygen Species Generation}

Cells were cultured in 96-well plates $\left(2.5 \times 10^{5}\right.$ cells $\left./ \mathrm{mL}\right)$, treated for $1 \mathrm{~h}$ with EE, EAF $(2.5-5 \mu \mathrm{g} / \mathrm{mL})$ or the antioxidant reference quercetin (QT; $3 \mu \mathrm{g} / \mathrm{mL})$. Then, cells were incubated with $\mathrm{H}_{2}$ DCF-DA $(10 \mu \mathrm{M})$ for 45 min at $37^{\circ} \mathrm{C}$ and exposed to UVB or UVA radiations. The fluorescence was detected immediately after UV exposure at $488 / 525 \mathrm{~nm}$ of excitation/emission (Victor $\mathrm{X} 3$, Perkin-Elmer). Protein concentrations were measured using Bio-Rad protein assay reagent (Bio-Rad, USA). ${ }^{17}$

\section{Reduced Glutathione}

Cells were cultured in 6-well plates $\left(4 \times 10^{5}\right.$ cells $\left./ \mathrm{mL}\right)$ and treated for $1 \mathrm{~h}$ with EE, EAF $(2.5-5 \mu \mathrm{g} / \mathrm{mL})$ or QT $(3 \mu \mathrm{g} / \mathrm{mL})$. Then, cells were exposed to UVB or UVA radiations and incubated for $24 \mathrm{~h}$ at $37^{\circ} \mathrm{C}$. Cell lysates were prepared by scraping cells in lysis buffer $[10 \mathrm{mM}$ tris- $\mathrm{HCl}(\mathrm{pH} 7.4)$, $1 \%$ Triton X-100] followed by sonication for $60 \mathrm{~s}$ and centrifugation at $10,000 \mathrm{~g} / 4^{\circ} \mathrm{C}$ for $10 \mathrm{~min}$. Supernatants were collected and protein concentrations were measured. ${ }^{17}$ Reduced glutathione (GSH) levels were analysed according to Hissin and Hilf, ${ }^{18}$ followed by fluorescence measurement at 350/420 nm excitation/emission. GSH standard was used for the calibration curve $(\mathrm{y}=23.837 \mathrm{x}+4074.1, \mathrm{r}=0.9994)$.

\section{Lipid Peroxidation}

Cells were cultured in 96-well plates $\left(2.5 \times 10^{5}\right.$ cells $\left./ \mathrm{mL}\right)$ and treated for $1 \mathrm{~h}$ with EE, EAF $(2.5-5 \mu \mathrm{g} / \mathrm{mL})$ or QT $(3 \mu \mathrm{g} / \mathrm{mL})$. Following treatment, cells were exposed to UVB or UVA radiations and incubated for $24 \mathrm{~h}$. Then, cells were incubated with DPPP probe $(20 \mu \mathrm{M})$ for $30 \mathrm{~min}$ at $37^{\circ} \mathrm{C}$. Fluorescence was detected at 351/460 $\mathrm{nm}$ of excitation/emission and protein concentrations were measured. ${ }^{17}$

\section{Propidium lodide Staining}

Cells were cultured in 24-well plates $\left(2.5 \times 10^{5}\right.$ cells $\left./ \mathrm{mL}\right)$ under glass coverslips and treated for $1 \mathrm{~h}$ with EE or EAF $(2.5 \mu \mathrm{g} / \mathrm{mL})$ to assess plasma membrane disruption. Following treatment, cells were exposed to UVB or UVA radiations and incubated for $24 \mathrm{~h}$ at $37^{\circ} \mathrm{C}$. Treatment for 30 min with digitonin $(4 \mu \mathrm{g} / \mathrm{mL})$ was used as a control of plasma membrane disruption. Then, cells were incubated with propidium iodide (PI) $(0.2 \mu \mathrm{g} / \mathrm{mL})$ for $5 \mathrm{~min}$ at room temperature, and images recorded under fluorescence microscope (Olympus BX51, Tokyo, Japan) at 200x magnification.

\section{Isolation and Identification of Compounds from Bioactive Plant Material}

The plant material that showed the greatest antioxidant and photochemoprotective potential, EAF, was submitted to column chromatography and other procedures to isolate its antioxidant compounds. Vitexin (1) and isoquercetin (2) were identified based on 
their spectroscopic data (1D and 2D NMR) (supplementary material) and comparison with the literature. ${ }^{19,20}$

\section{Data Analysis}

Statistical analyses were performed using GraphPad Prism 6. Results were expressed as mean \pm standard deviation of three independent observations, analyzed using one-way ANOVA followed by Tukey's multiple range test. Statistical significance was set at $p<0.05$.

\section{RESULTS}

\section{Total Phenolic Content and Antioxidant Potential of Plant Materials}

The results of TP content were shown in Table 1. EE followed by EAF presented the best results. No phenolic substances were detected in the HF under the conditions used.

The antioxidant potential of samples and reference antioxidants QT and BHT were also presented in Table 1. EAF and EE exhibited the best activities in regard to the five methodologies employed. They exhibited FRAP values of 1.92 and $1.20 \mathrm{mmol}$ TE/g, respectively. For ABTS scavenging capacity, EAF (1.94 mmol TE/g) and MF $(2.04 \mathrm{mmol}$ $\mathrm{TE} / \mathrm{g})$ presented similar activity, followed by EE (1.30 mmol TE/g). For DPPH scavenging capacity, EAF $\left(\mathrm{IC}_{50}=12.6 \mu \mathrm{g} / \mathrm{mL}\right.$ ) was more effective and significant similar to BHT $\left(\mathrm{IC}_{50}=12.4 \mu \mathrm{g} / \mathrm{mL}\right)$, followed by $\mathrm{EE}$ $\left(\mathrm{IC}_{50}=20.5 \mu \mathrm{g} / \mathrm{mL}\right)$. For ORAC values EAF $(12.74 \mathrm{mmol} \mathrm{TE} / \mathrm{g})$ showed the best ROO ${ }^{\bullet}$ scavenging activity, followed by EE $(4.23 \mathrm{mmol} \mathrm{TE} / \mathrm{g})$ and MF (4.67 mmol TE/g), which were comparable to each other, and with superior activity to BHT $(1.82 \mathrm{mmol} \mathrm{TE} / \mathrm{g})$. And, for XO values, EAF $\left(\mathrm{IC}_{50}=0.25 \mu \mathrm{g} / \mathrm{mL}\right)$ presented the best $\mathrm{O}_{2}{ }^{--}$scavenging activity, which was compared to QT $\left(\mathrm{IC}_{50}=0.14 \mu \mathrm{g} / \mathrm{mL}\right)$, followed by EE $\left(\mathrm{IC}_{50}=0.83\right.$ $\mu \mathrm{g} / \mathrm{mL})$.

Table 1: Total phenolic (TP) content and antioxidant capacity of ethanolic extract (EE), hexane (HF), ethyl acetate (EAF) and hydromethanolic (MF) fractions, and the reference antioxidants butyl hydroxytoluene (BHT) and quercetin (QT).

\begin{tabular}{|c|c|c|c|c|c|c|}
\hline & $\begin{array}{l}\text { TP } \\
\mathrm{mg}\end{array}$ & FRAP & $\begin{array}{c}\text { ABTS } \\
\mathrm{mmol} T E / g\end{array}$ & ORAC & $\begin{array}{l}\text { DPPH } \\
\qquad I_{50}(\end{array}$ & $\begin{array}{r}X O \\
\text { (mL) }\end{array}$ \\
\hline $\mathrm{EE}$ & $\begin{array}{c}415.6 \pm \\
12.3^{\mathrm{a}}\end{array}$ & $\begin{array}{c}1.20 \pm \\
0.01^{\mathrm{a}}\end{array}$ & $\begin{array}{c}1.30 \pm \\
0.04^{\mathrm{a}}\end{array}$ & $\begin{array}{c}4.23 \pm \\
0.19^{\mathrm{a}}\end{array}$ & $\begin{array}{c}20.5 \pm \\
0.2^{\mathrm{a}}\end{array}$ & $\begin{array}{c}0.83 \pm \\
0.04^{\mathrm{a}}\end{array}$ \\
\hline $\mathrm{HF}$ & nd & $\begin{array}{c}0.37 \pm \\
0.01^{\mathrm{b}}\end{array}$ & $\begin{array}{c}0.39 \pm \\
0.02^{\mathrm{b}}\end{array}$ & $\begin{array}{c}0.80 \pm \\
0.07^{\mathrm{b}}\end{array}$ & $\begin{array}{c}91.1 \pm \\
0.4^{\mathrm{b}}\end{array}$ & $\begin{array}{c}7.56 \pm \\
0.17^{b}\end{array}$ \\
\hline EAF & $\begin{array}{c}317.9 \pm \\
14.2^{\mathrm{b}}\end{array}$ & $\begin{array}{c}1.92 \pm \\
0.03^{c}\end{array}$ & $\begin{array}{c}1.94 \pm \\
0.04^{c}\end{array}$ & $\begin{array}{c}12.74 \pm \\
1.08^{\mathrm{c}}\end{array}$ & $\begin{array}{c}12.6 \pm \\
0.4^{\mathrm{c}}\end{array}$ & $\begin{array}{c}0.25 \pm \\
0.01^{\mathrm{c}}\end{array}$ \\
\hline $\mathrm{MF}$ & $\begin{array}{c}221.8 \pm \\
8.6^{c}\end{array}$ & $\begin{array}{c}1.05 \pm \\
0.01^{\mathrm{d}}\end{array}$ & $\begin{array}{c}2.04 \pm \\
0.03^{c}\end{array}$ & $\begin{array}{c}4.67 \pm \\
0.40^{\mathrm{a}}\end{array}$ & $\begin{array}{c}21.8 \pm \\
0.6^{\mathrm{d}}\end{array}$ & $\begin{array}{c}1.66 \pm \\
0.03^{\mathrm{d}}\end{array}$ \\
\hline BHT & - & $\begin{array}{c}3.73 \pm \\
0.05^{e}\end{array}$ & $\begin{array}{c}6.54 \pm \\
0.14^{\mathrm{d}}\end{array}$ & $\begin{array}{l}1.82 \pm \\
0.05^{\mathrm{b}}\end{array}$ & $\begin{array}{c}12.4 \pm \\
0.5^{\mathrm{c}}\end{array}$ & $>30^{e}$ \\
\hline QT & - & $\begin{array}{c}21.20 \pm \\
0.11^{\mathrm{f}}\end{array}$ & $\begin{array}{c}32.57 \pm \\
0.26^{\mathrm{e}}\end{array}$ & $\begin{array}{c}26.93 \pm \\
1.78^{\mathrm{d}}\end{array}$ & $\begin{array}{c}2.9 \pm \\
0.0^{e}\end{array}$ & $\begin{array}{c}0.14 \pm \\
0.00^{c}\end{array}$ \\
\hline
\end{tabular}

Experimental data: mean $\pm \mathrm{SD}(n=3)$; nd $=$ not detected; GAE $=$ gallic acid equivalent; $\mathrm{TE}=$ Trolox equivalent; $\mathrm{IC}_{50}=50 \%$ inhibitory concentration. Different letters for each method indicate a significant difference $(p<0.05)$.
Effect of Ethanolic Extract and Ethyl Acetate Fraction in the Prevention of UVB- and UVA-Induced Cytotoxicity in Fibroblasts

The 24h-treatment with EE resulted in no significant alteration in cell viability up to $10 \mu \mathrm{g} / \mathrm{mL}$, however the concentrations of $20-200 \mu \mathrm{g} / \mathrm{mL}$ exhibited a significant decrease in cell viability. Whereas, EAF treatment showed no significant reduction in viability in all concentrations tested, compared to control (untreated cells) (Figure 1A).

Concentrations that exhibited no significant change or minimal alterations in cell viability were selected to evaluate the effect of plant materials in prevent UV-induced cytotoxicity. Figures $2 \mathrm{~B}$ and $2 \mathrm{C}$ show that UVB and UVA radiations caused a reduction in cell viability by $34 \%$ and $10 \%$ respectively, compared with respective controls (untreated and non-irradiated cells). However, EE and EAF treatments reduced cell cytotoxicity induced by these radiations. For UVB exposure, EAF at $2.5-20 \mu \mathrm{g} / \mathrm{mL}$ reduced cell death by $10.7-7 \%$, and EE at $2.5-10 \mu \mathrm{g} /$ $\mathrm{mL}$ reduced cell death by $8.9-7.5 \%$, compared with UVB control (Figure 1B). For UVA exposure, EAF at $2.5-5 \mu \mathrm{g} / \mathrm{mL}$ reduced cell death by 6.2 $5.6 \%$, and $\mathrm{EE}$ at $2.5 \mu \mathrm{g} / \mathrm{mL}$ reduced cell death by $6 \%$, compared with UVA control (Figure 1C). Based on these results, the concentrations of 2.5 and $5 \mu \mathrm{g} / \mathrm{ml}$ were selected for further investigation.

\section{Effects of Ethanolic Extract and Ethyl Acetate Fraction in} the Inhibition of UVB- and UVA-Induced Oxidative Stress in Fibroblasts

Oxidative stress levels were evaluated measuring ROS production and GSH depletion in treated and irradiated cells. UVB and UVA caused a significant ROS increase in untreated and irradiated cells by 31 -fold and 6-fold, respectively, compared with untreated and non-irradiated cells (Figure 2A). However, plant materials exhibited ROS scavenging activity, compared with untreated and irradiated cells. EAF treatment exhibited the best effect $(2.5 / 5 \mu \mathrm{g} / \mathrm{mL}$, UVB: EE $18 \% / 25 \%$, EAF $30 \% / 32 \%$; UVA: EE $9 \% / 22 \%$, EAF $13 \% / 27 \%$ of ROS inhibition). Furthermore, UVB and UVA exposure provoked decrease in GSH levels by $47 \%$ and
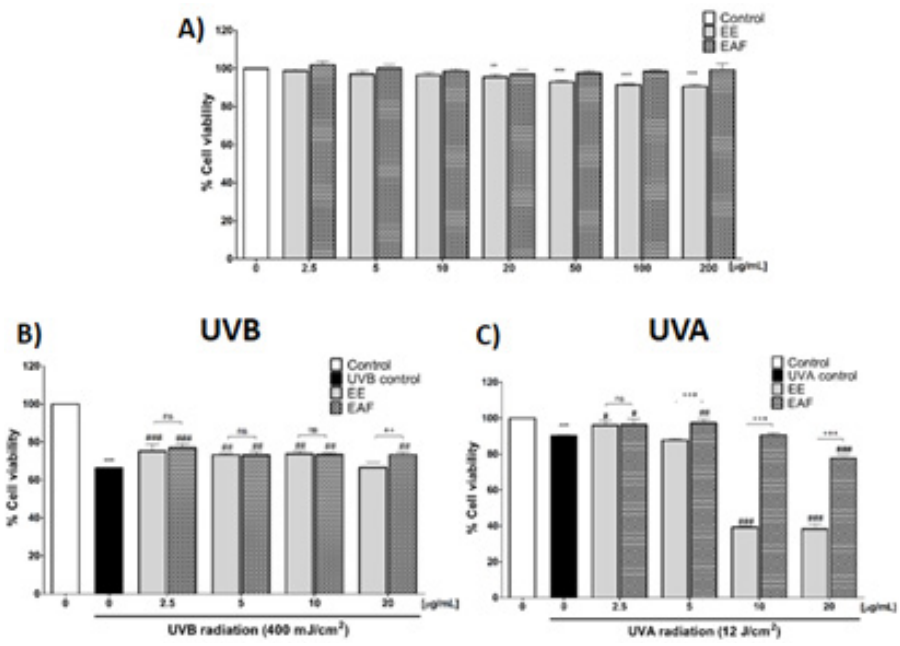

Figure 1: Cell viability evaluation. A) L929 fibroblasts were treated with EE and EAF (2.5-200 $\mu \mathrm{g} / \mathrm{mL})$ for $24 \mathrm{~h}$. B) and C) L929 fibroblasts were treated with EE and EAF $(2.5-20 \mu \mathrm{g} / \mathrm{mL}) 1 \mathrm{~h}$ before exposure to UVB or UVA radiations and subsequently incubated for $24 \mathrm{~h}$. Control: untreated and non-irradiated cells. UVB/UVA control: UVB or UVA irradiated and untreated cells. ${ }^{* *} p<0.01$ and ${ }^{* * *} p<0.0001$ compared with control. $\# p<0.05$, \#\#p $<0.01$ and \#\#\#p $<0.0001$ compared with UVB/UVA control, $++p<0.01$ and $+++p<0.0001$, ns: not significant. 
$34 \%$, respectively, compared with untreated and non-irradiated cells (Figure 2B). However, EE and EAF treatments were able to prevent GSH depletion, especially EAF $(2.5 / 5 \mu \mathrm{g} / \mathrm{mL}$, UVB: EE 38\%/40\%, EAF $63 \% / 50 \%$; UVA: EE $21 \% / 10 \%$, EAF 27\%/19\%), compared with untreated and irradiated cells.

\section{Effects of Ethanolic Extract and Ethyl Acetate Fraction in the Inhibition of UVB- and UVA-Induced Cellular Damage in Fibroblasts}

As shown in Figure 3, UVB- and UVA-irradiated fibroblasts presented $100 \%$ and $53 \%$ of increase in lipid peroxidation, respectively, compared with untreated and non-irradiated cells. However, EAF and EE treatments effectively inhibited lipid peroxidation $(2.5 / 5 \mu \mathrm{g} / \mathrm{mL}$, UVB: EE $28 \% / 24 \%$, EAF $38 \% / 33 \%$; UVA: EE $19 \% / 5 \%$, EAF $19 \% / 19 \%$ of inhibition). The lowest concentration of plant materials $(2.5 \mu \mathrm{g} / \mathrm{mL})$, which was more effective in inhibiting UV-induced alterations was selected to evaluate membrane integrity (Figure 4). An increase in red-stained cells was observed in UVB- and UVA-irradiated and untreated fibroblasts, as well as in digitonin-treated cells, used as positive control, indicating disruption of plasma membrane in comparison with non-irradiated cells. However, EE and EAF treatments attenuated membrane damage (lowest number of PI-stained cells, compared with UVB/UVA controls).

\section{DISCUSSION}

Several studies have demonstrated that treatment using plant extracts with antioxidant properties can attenuate the adverse effects of UV-mediated oxidative damage caused as a result of increased ROS levels. ${ }^{21,22}$ Thereby, the present study attempts to evaluate the antioxidant and photochemoprotective capacities of $\mathrm{EE}$ and fractions from $S$. polyphylla leaves.

First, this work verified the content of phenolic compounds assessed by Folin-Ciocalteu reagent. Phenolic compounds are the most wellknown naturally occurring antioxidant substances, presenting ability to directly scavenge ROS and inhibit free radical generation. ${ }^{23} \mathrm{EE}$ and EAF showed the best results, suggesting that ethyl acetate used in the
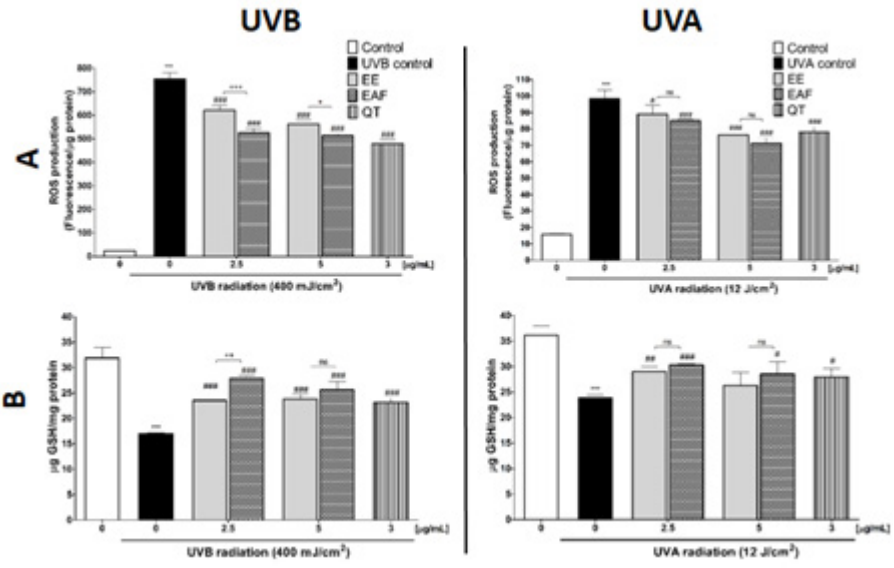

Figure 2: Effects of treatments with $\mathrm{EE}, \mathrm{EAF}(2.5$ and $5 \mu \mathrm{g} / \mathrm{mL})$ or reference antioxidant quercetin (QT; $3 \mu \mathrm{g} / \mathrm{mL}$ ) $1 \mathrm{~h}$ before $U V$ irradiation on the reduction of oxidative stress in L929 cells. A: ROS production was evaluated immediately after UVB or UVA exposure. B: GSH levels were determined 24h after UVB or UVA exposure. Control: untreated and non-irradiated cells. UVB/UVA control: UVB or UVA irradiated and untreated cells. ${ }^{* * *} p<0.0001$ compared with control. \#p $<0.05$, \#\#p $<0.01$ and \#\#\#p $<0.0001$ compared with UVB/UVA control, $++p<0.01$ and $+++p<0.0001$, ns: not significant. partition procedure was the most efficient solvent to extract the reducing compounds from EE.

Subsequently, we analyzed the antioxidant potential of plant materials using five methodologies. Overall, EAF followed by EE presented the best results. The ability of plant materials to neutralize $\mathrm{ROO}^{\circ}$ and $\mathrm{O}_{2}{ }^{-}$ was higher than that of the synthetic antioxidant BHT, and EAF capacity to scavenge $\mathrm{O}_{2}^{-{ }^{--}}$was similar to natural antioxidant QT. The ROO• and $\mathrm{O}_{2}{ }^{--}$play important roles in oxidative stress caused by UV exposure. ROO disseminate lipid peroxidation throughout cellular environment, and $\mathrm{O}_{2}{ }^{--}$generate additional reactive species, including $\mathrm{H}_{2} \mathrm{O}_{2}$, and the free radicals $\mathrm{HO}^{*}$ and ROO.. ${ }^{1,3}$ These results indicated the ability of EE and EAF to partially block reactive species, and prevent chain reactions in the reaction medium.

Considering the antioxidant potential exhibited by EAF and EE, their photochemoprotective effects were assessed in L929 fibroblasts against UV radiation. This cell line was used based on previous studies that support L929 cells as a target of UV-induced damage. ${ }^{4}$ EAF treatment showed no significant cytotoxic effect for all concentrations tested.
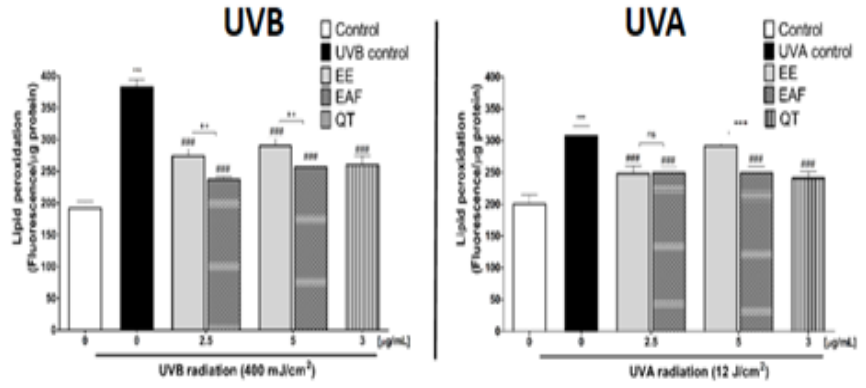

Figure 3: Effect of treatment with $\mathrm{EE}, \mathrm{EAF}(2.5$ and $5 \mu \mathrm{g} / \mathrm{mL}$ ) or reference antioxidant quercetin (QT; $3 \mu \mathrm{g} / \mathrm{mL}$ ) $1 \mathrm{~h}$ before UVB or UVA exposure on the reduction of lipid peroxidation in L929 cells. Control: untreated and non-irradiated cells. UVB/UVA control: UVB or UVA irradiated and untreated cells. ${ }^{* * *} p<0.0001$ compared with control. \#\#\# $<0.0001$ compared with UVB/UVA control. $++p<0.01$ and $+++p<0.0001$, ns: not significant.

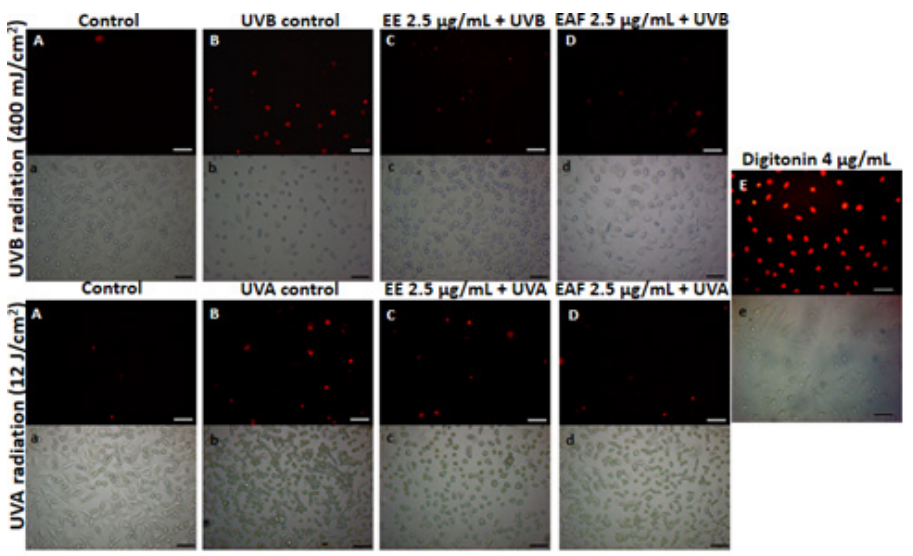

Figure 4: Effect of treatment with $\operatorname{EE}$ or $\operatorname{EAF}(2.5 \mu \mathrm{g} / \mathrm{mL}) 1 \mathrm{~h}$ before UVB or UVA exposure on the reduction of plasma membrane disruption in L929 cells $24 \mathrm{~h}$ following UV exposure, or treatment with control digitonin $(4 \mu \mathrm{g} / \mathrm{mL})$ for $30 \mathrm{~min}$. Cells were stained with $\mathrm{PI}$ and observed under a fluorescence microscope. Images A-E represent the PI fluorescence, and images a-e represent the differential interference contrast. Control: untreated and non-irradiated cells. UVB/UVA control: UVB or UVA irradiated and untreated cells. Images are representative of three independent experiments (Scale bar: $100 \mu \mathrm{m}$ ). 
Whereas, EE treatment caused no significant alterations in cell viability up to $10 \mu \mathrm{g} / \mathrm{mL}$, suggesting that EE contains cytotoxic substances that are not present in its EAF fraction. ${ }^{24}$

Cellular oxidative stress is a result of a redox imbalance in favor of ROS production against the antioxidant defense system. Both UVB and UVA are responsible for ROS overproduction in the skin. UV photons react with cellular photosensitizers undergoing electron-transfer reactions to generate ROS, including ${ }^{1} \mathrm{O}_{2}, \mathrm{H}_{2} \mathrm{O}_{2}$, and free radicals $\mathrm{O}_{2}{ }^{--}, \mathrm{HO} \cdot$ and ROO ${ }^{1,3}$ Moreover, prolonged exposure to UV radiation interferes with the antioxidant defense levels. GSH is a non-enzymatic defense component, acting as a cofactor for several antioxidant enzymes and directly scavenging ROS. ${ }^{3}$ Therefore, prevent ROS generation and GSH depletion are well-established strategies to prevent skin injuries. In the present work, EE and EAF effectively decreased ROS levels and prevented GSH reduction in treated and irradiated cells, exposed by both UVB and UVA radiations.

The increase of ROS and depletion of GSH induced by UV radiation, generate a redox disorder in skin cells, leading to a variety of oxidative damages, including lipid peroxidation and loss of membrane integrity. Lipid peroxidation can lead to cell death by the generation of intermediate reactive species, which cause alterations in proteins and nucleic acids, and impairs membrane structural integrity. ${ }^{25}$ The cell membrane structural intergrity is essential for homeostatic maintenance in cells, the loss of its integrity is intrinsically related to cell death. ${ }^{26}$ In this work EE and EAF were able to prevent oxidative damages in fibroblast cells, preventing lipid peroxidation and cellular membrane disruption.

EAF exhibited the greatest photochemoprotective effects. Thus, a phytochemical study was performed to investigate the constituents that contribute to its bioactivity. The study afforded the identification of vitexin (1) and isoquercetin (2). The antioxidant potential of these flavonoids is well-known. Wang et al. ${ }^{27}$ reported a great scavenging potential of isoquercetin (DPPH assay $\mathrm{IC}_{50} 7.63 \mu \mathrm{g} / \mathrm{mL}$ and ORAC assay $15.35 \mathrm{mmol} \mathrm{TE} / \mathrm{g}$ ), and Kang et al. ${ }^{28}$ reported an ORAC value of $14.8 \mathrm{mmol} \mathrm{TE} / \mathrm{g}$ for vitexin. The photochemoprotective effects of vitexin was demonstrated by Kim et al. ${ }^{29}$ and Ferreira et al..$^{30}$ presenting ROS scavenging activity and decrease of lipid peroxidation in UVBirradiated fibroblasts. Additionally, emulsion containing EAF from Nectandra cuspidata, containing vitexin, protected hairless mice from UVB-induced oxidative stress. ${ }^{30}$ In accordance with these findings, the protective effects of EE and EAF against UVB and UVA radiations may be linked to the presence of these flavonoids. Vitexin and isoquercetin have previously been identified in the genus Senegalia. ${ }^{6,7}$ However, this is the first report for S. polyphylla leaves.

\section{CONCLUSION}

Oxidative stress reflects the inability of cells to deal with an excessive increase in ROS production, and the topical use of antioxidant agents is an effective tool to attenuate oxidative damage in skin cells. The present study showed that polyphenol-enriched plant materials from S. polyphylla leaves, EE and EAF, exhibited high antioxidant potential and effectively protected L929 fibroblasts against UVB- and UVA-induced oxidative stress. Notably EAF showed the best ability to attenuate cell cytotoxicity and to reduce ROS generation, GSH depletion, lipid peroxidation, and loss of plasma membrane integrity. These results indicate the potential of S. polyphylla as a source of natural active agents for the development of topical products for skin protection against oxidative stress and alterations induced by sun exposure.

\section{ACKNOWLEDGEMENT}

The authors are grateful to CAPES (Brazilian Federal Agency for Support and Evaluation of Graduate Education within the Ministry of Education of Brazil).

\section{CONFLICT OF INTEREST}

The authors declare no conflict of interest.

\section{ABBREVIATIONS}

ABTS: 2,2'-azinobis (3-ethylbenzothiazoline -6-sulfonic acid) diammonium salt; BHT: butylhydroxytoluene; DPPH: 2,2-diphenyl-1picrylhydrazyl; DPPP: diphenyl-1-pyrenylphosphine; EAF: ethyl acetate fraction; EE: ethanol extract; FRAP: ferric reducing antioxidant power; GSH: reduced glutathione; $\mathbf{H}_{2}$ DCF-DA: $2^{\prime}, 7^{\prime}$ dichlorodihydrofluorescein diacetate; HF: hexane fraction; MF: hydro-methanolic fraction; NMR: nuclear magnetic resonance; ORAC: oxygen radical absorbance capacity; PI: propidium iodide; QT: quercetin; ROS: reactive oxygen species; UVA: ultraviolet A; UVB: ultraviolet B; XO: xanthine/luminol/ xanthine oxidase system.

\section{REFERENCES}

1. PolefkaTG, MeyerTA, Agin PP, Bianchini RJ. Effects of solar radiation on the skin. J Cosmet Dermatol. 2012;11(2):134-43. doi: 10.1111/j.1473-2165.2012.00614.x PMID 22672278.

2. Nichols JA, Katiyar SK. Skin photoprotection by natural polyphenols: antiinflammatory, antioxidant and DNA repair mechanisms. Arch Dermatol Res. 2010;302(2):71-83. doi: 10.1007/s00403-009-1001-3, PMID 19898857.

3. Valko M, Leibfritz D, Moncol J, Cronin MT, Mazur M, Telser J. Free radicals and antioxidants in normal physiological functions and human disease. Int J Biochem Cell Biol. 2007;39(1):44-84. doi: 10.1016/j.biocel.2006.07.001, PMID 16978905.

4. Cavinato M, Waltenberger B, Baraldo G, Grade CVC, Stuppner H, Jansen-Dürr P. Plant extracts and natural compounds used against UVB-induced photoaging. Biogerontology. 2017;18(4):499-516. doi: 10.1007/s10522-017-9715-7, PMID 28702744

5. Seigler DS, Morim MP, Barros MJF, Ebinger JE. A new species of Senegalia (Fabaceae) from Brazil. Phytotaxa. 2013;132(1):59-63. doi: 10.11646/phytotaxa.132.1.6.

6. Suarez SS, Cabrera JL, Juliani HR. Flavonoids of Argentinian Acaciae species An Associacion Quim. 1982;70:647-9.

7. Voirin B, Bayet C, Favre-Bonvin J, Nair AGR, Krishnakumary P. Flavonoids from the flowers of Acacia latifolia. J Nat Prod. 1986;49(5):943-. doi: 10.1021/ np50047a040

8. Lin HY, Chang ST. Antioxidant potency of phenolic phytochemicals from the root extract of Acacia confusa. Ind Crops Prod. 2013;49:871-8. doi: 10.1016/j. indcrop.2013.07.001.

9. Sowndhararajan K, Joseph JM, Manian S. Antioxidant and Free Radical Scavenging Activities of Indian Acacias: Acacia Leucophloea (Roxb.) Willd., Acacia Ferruginea Dc., Acacia Dealbata Link. and Acacia Pennata (L.) Willd. Int J Food Prop. 2013;16(8):1717-29. doi: 10.1080/10942912.2011.604895.

10. León de Pinto G, Sanabria L, Martínez M, Beltrán O, Manuel Igartuburu J. Structural elucidation of proteic fraction isolated from Acacia glomerosa gum. Food Hydrocoll. 2002;16(6):599-603. doi: 10.1016/S0268-005X(02)00022-X

11. Benzie IFF, Strain JJ. The ferric reducing ability of plasma (FRAP) as a measure of "antioxidant power": the FRAP assay. Anal Biochem. 1996;239(1):70-6. doi: 10.1006/abio.1996.0292, PMID 8660627.

12. Re R, Pellegrini N, Proteggente A, Pannala A, Yang M, Rice-Evans C. Antioxidant activity applying an improved ABTS radical cation decolorization assay. Free Radic Biol Med. 1999;26(9-10):1231-7. doi: 10.1016/s0891-5849(98)003153, PMID 10381194.

13. Brand-Williams W, Cuvelier ME, Berset C. Use of a free radical method to evaluate antioxidant activity. LWT - Food Science and Technology. 1995;28(1):25-30. doi: 10.1016/S0023-6438(95)80008-5.

14. Ou B, Hampsch-Woodill M, Prior RL. Development and validation of an improved oxygen radical absorbance capacity assay using fluorescein as the fluorescent probe. J Agric Food Chem. 2001;49(10):4619-26. doi: 10.1021/ jf010586o, PMID 11599998.

15. Girotti S, Fini F, Ferri E, Budini R, Piazzi S, Cantagalli D. Determination of superoxide dismutase in erythrocytes by a chemiluminescent assay. Talanta. 2000;51(4):685-92. doi: 10.1016/s0039-9140(99)00332-x, PMID 18967900

16. Borenfreund $E$, Puerner JA. A simple quantitative procedure using mono- 
layer cultures for cytotoxicity assays (HTD/NR-90). J Tissue Cult Methods. 1985;9(1):7-9. doi: 10.1007/BF01666038.

17. Bradford MM. A rapid and sensitive method for the quantitation of microgram quantities of protein utilizing the principle of protein-dye binding. Anal Biochem. 1976;72:248-54. doi: 10.1006/abio.1976.9999, PMID 942051.

18. Hissin PJ, Hilf R. A fluorometric method for determination of oxidized and reduced glutathione in tissues. Anal Biochem. 1976;74(1):214-26. doi: 10.1016/0003-2697(76)90326-2, PMID 962076.

19. El-Kashak WA, Hamed AR, El-Raey M, Elshamy Al, Abd-Ellatef GEF. Antiproliferative, antioxidant and antimicrobial activities of phenolic compounds from Acrocarpus fraxinifolius. J Chem Pharm Res. 2016;8:520-8.

20. Ferreira LDAO, Oliveira MM, Faleiro FL, Scariot DB, Boeing JS, Visentainer JV, Romagnolo MB, Nakamura CV, Truiti MDCT. Antileishmanial and antioxidant potential of fractions and isolated compounds from Nectandra cuspidata. Nat Prod Res. 2018;32(23):2825-8. doi: 10.1080/14786419.2017.1378214. PMID 28927293.

21. Calò R, Marabini L. Protective effect of Vaccinium myrtillus extract against UVAand UVB-induced damage in a human keratinocyte cell line (Hacat Cells). J Photochem Photobiol B. 2014;132:27-35. doi: 10.1016/j.jphotobiol.2014.01.013, PMID 24577051.

22. Fehér $P$, Ujhelyi Z, Váradi J, Fenyvesi F, Róka $E$, Juhász $B$, Varga $B$, Bombicz $M$ Priksz D, Bácskay I, Vecsernyés M. Efficacy of pre- and post-treatment by topical formulations containing dissolved and suspended Silybum marianum against UVB-induced oxidative stress in guinea pig and on Hacat keratinocytes. Molecules. 2016;21(10):1-21. doi: 10.3390/molecules21101269, PMID 27669200.

23. Stepanić V, Gall Trošelj KG, Lučić B, Marković Z, Amić D. Bond dissociation free energy as a general parameter for flavonoid radical scavenging activity. Food Chem. 2013;141(2):1562-70. doi: 10.1016/j.foodchem.2013.03.072, PMID
23790952.

24. Sotler R, Poljšak B, Dahmane R, Jukić T, Pavan Jukić DP, Rotim C, Trebše P, Starc A. Prooxidant activities of antioxidants and their impact on health. Acta Clin Croat. 2019;58(4):726-36. doi: 10.20471/acc.2019.58.04.20, PMID 32595258.

25. Gaschler MM, Stockwell BR. Lipid peroxidation in cell death. Biochem Biophys Res Commun. 2017;482(3):419-25. doi: 10.1016/j.bbrc.2016.10.086, PMID 28212725.

26. Zhang Y, Chen X, Gueydan C, Han J. Plasma membrane changes during programmed cell deaths. Cell Res. 2018;28(1):9-21. doi: 10.1038/cr.2017.133, PMID 29076500.

27. Wang L, Yang X, Qin P, Shan F, Ren G. Flavonoid composition, antibacterial and antioxidant properties of Tartary buckwheat bran extract. Ind Crops Prod. 2013;49:312-7. doi: 10.1016/j.indcrop.2013.04.039.

28. Kang J, Li Z, Wu T, Jensen GS, Schauss AG, Wu X. Anti-oxidant capacities of flavonoid compounds isolated from acai pulp (Euterpe oleracea Mart.). Food Chem. 2010;122(3):610-7. doi: 10.1016/j.foodchem.2010.03.020.

29. Kim JH, Lee BC, Kim JH, Sim GS, Lee DH, Lee KE, Yun YP, Pyo HB. The isolation and antioxidative effects of vitexin from Acer palmatum. Arch Pharm Res. 2005;28(2):195-202. doi: 10.1007/BF02977715, PMID 15789751

30. Dos Anjos Oliveira Ferreira L, de Paula Barros de Melo C, Saito P, Iwanaga CC, Nakamura CV, Casagrande R, da Conceição Torrado Truiti M. Nectandra cuspidata fraction and the isolated polyphenols protect fibroblasts and hairless mice skin from UVB-induced inflammation and oxidative stress. J Photochem Photobiol B. 2020;205:111824. doi: 10.1016/j.jphotobiol.2020.111824, PMID 32126496.

Cite this article: Daré RG, Ferreira LAO, Ribeiro FM, Visentainer JV, Nakamura CV, Truiti MCT. Photochemoprotective Effects of Ethyl Acetate Fraction from Senegalia polyphylla Leaves in Ultraviolet-Irradiated L929 Fibroblasts. Free Radicals and Antioxidants. $2021 ; 11(1): 7-12$. 